\title{
Legal and Administrative Challenges of Alternative Dispute Resolution (ADR) as a Peaceful Means of Resolving the Land Dispute in the Rural Areas of Bangladesh
}

\author{
Md. Manjur Hossain Patoari1,2*\#, Amir Husin Mohd Nor ${ }^{1}$, Muhammad Nizam Bin Awang1, \\ Abdul Hamid Chowdhury33, Jaforullah Talukder ${ }^{4}$ \\ ${ }^{1}$ Faculty of Syariah and Law, Universiti Sains Islam Malaysia, Nilai, Malaysia \\ ${ }^{2}$ Faculty of Law, International Islamic University Chittagong, Chittagong, Bangladesh \\ ${ }^{3}$ Faculty of Business Administration, International Islamic University Chittagong, Chittagong, Bangladesh \\ ${ }^{4}$ Faculty of Law, University of Chittagong, Chittagong, Bangladesh \\ Email: "manjuiiuc3@yahoo.com
}

How to cite this paper: Patoari, M. M. H., Nor, A. H. M., Awang, M. N. B., Chowdhury, A. H., \& Talukder, J. (2020). Legal and Administrative Challenges of Alternative Dispute Resolution (ADR) as a Peaceful Means of Resolving the Land Dispute in the Rural Areas of Bangladesh. Beijing Law Review, 11, 415-428.

https://doi.org/10.4236/blr.2020.112026

Received: February 27, 2020

Accepted: April 10, 2020

Published: April 13, 2020

Copyright $\odot 2020$ by author(s) and Scientific Research Publishing Inc. This work is licensed under the Creative Commons Attribution International License (CC BY 4.0).

http://creativecommons.org/licenses/by/4.0/ (c) (i) Open Access

\begin{abstract}
Alternative Dispute Resolution (ADR) is an innovative movement in the civil justice system of Bangladesh including land conflict. Traditional judicial process of Bangladesh especially land litigation is time consuming, expensive and very much complex. People involved in the land conflict, are fear to go to the court to settle their dispute due to unreasonable delay, expenses and unbearable sufferings and most of them prefer ADR as a way of resolving their dispute. Bangladesh has emphasized Alternative Dispute Resolution (ADR) as a means to resolve civil conflict as it saves time, money and energy of conflicting parties, reduces backlog of cases and work volume of court officials and also saves valuable time of the court. Recently ADR has become a popular means of settlement of land conflict among the people of Bangladesh as it is confidential, informal and relieves the parties from sufferings. The main objective of this study is to identify the legal and administrative challenges of ADR as a means of settlement of land conflict in Bangladesh and also to suggest an avenue for the complete success of ADR as an effective means to resolve land conflict in the rural areas of Bangladesh. This study is qualitative in nature which is conducted on the basis of secondary data. Data are collected from various journals, books, reports, newspaper writing and decision of apex court of Bangladesh. The core implication of this research is that it will open a new avenue for the policy maker of the country and the conflicting parties would be able to resolve their land dispute through a peaceful means.
\end{abstract}




\section{Keywords}

Alternative Dispute Resolution (ADR), Access to Justice, Land Conflict, Challenges of ADR, Peaceful Means

\section{Introduction}

In adversarial system of justice like Bangladesh, justice seeker has to suffer more due to lack of proper court management system, shortage of court officials, unreasonable delay, expenses, corruption and procedural complexity, efficient and dutiful court officials and lawyers. But getting justice is one of the fundamental rights which is guaranteed in the constitution almost all the countries of the world (Islam, 2011). Article 27, 28 and 31 ensure that every citizen is equal before the law and there will have no discrimination between them. The Universal Declaration of Human Rights, 1948 also recognizes these rights as according to UDHR every person is entitled to all rights as enunciated in the declaration without any sorts of discrimination either on the ground of race or color or sex or place of birth etc. Conflict in any society is a common phenomenon and in poor undeveloped and overpopulated countries; like Bangladesh it is at an extreme level. Land conflict in Bangladesh is very old as it has taken a long time after its independence but land management system has not developed at the expected level (Chowdhury, 2017). Land conflict among close relatives and neighbors is the main source of litigations in the rural area of Bangladesh. Land conflict in Bangladesh is such nature that quickly descends into bloodshed and twenty percent (20\%) of total acid burn cases derived from conflict over land (Akram, 2017). About eighty percent (80\%) of the total pending cases in Bangladesh arisen from land (Hoque, 2000). If land conflict can be removed almost fifty percent $(50 \%)$ of the criminal cases will be reduced. It is the fundamental duty of every modern democratic state to ensure justice for every litigating party speedily and with minimum cost. The responsibility to ensure the rights of the citizens and delivery of justice is mainly vested on legal institutions including courts. But due to various reasons like inordinate delay, high cost of litigation, procedural complexity, lack of efficient and dutiful court officials, the judiciary has failed to ensure easy and speedy justice for all.

Any kind of conflict including land is like a fatal disorder. It is better for all to resolve the conflict as soon as possible because one conflict opens the door of another conflict. The bet is to resolve a conflict in its raising moment. "Behind almost every human conflict some feel dismissed, discounted, disenfranchised or disrespected. Unresolved tensions that may have immersed below the surface can resurface and make situations difficult" (Singh, 2016).

It is true that theoretically the legal system of Bangladesh ensures access to justice for all but in reality it is not so easy for disadvantaged segments of the country. Only the resourceful and powerful persons are able to get justice as in Bangladesh in order to get justice one must have money and muscle power 
(Naser, 2006). Bangladesh has only way to choose ADR mechanism to get relief from this situation. As ADR mechanism is non-formal, easy, speedy, cost effective, confidential, and accepted method especially among the poor and disadvantaged group of the country, by-pass ineffective and complex court system and procedure, is a revolution in the settlement of civil conflict in Bangladesh. Former chief justice of Bangladesh Sayed J. R. Modasher Hossain stated in "South Asian Regional Workshop on Alternative Dispute Resolution" held on $7^{\text {th }}$ and $8^{\text {th }}$ March, 2004 at British Council, Dhaka that "in our present legal system, increasing expenses of litigation, delay in disposal of cases and huge backlogs have virtually shaken the confidence of the people in the judiciary. In this backdrop, we cannot but ponder about the device like ADR which is potentially useful for reducing the backlogs and delay in some cases of our courts. Alternative dispute resolution, being much cheaper and speedier than the existing legal system, can greatly mitigate the sufferings of poor litigants". As ADR mechanism is voluntary, informal and parties are able to express their own story in their own words, it has become a popular method of settlement of land conflict in the rural area of Bangladesh.

Although overall success of ADR mechanism in Bangladesh is at a satisfactory level especially in the settlement of family dispute its success is more than expectation but in the settlement of land conflict its success is not remarkable. The root cause of most of the conflict in the rural area of Bangladesh is land. So without remarkable success in the settlement of land conflict, ADR mechanism cannot become an effective dispute settlement method in Bangladesh. Lack of confidence among the parties, lack of awareness regarding advantages of ADR, lack of accountability, shortage of effective and dutiful mediator in case of informal ADR (outside of court), lack of cooperation of lawyers, disconnect between rules and reality are the major legal and administrative challenges of ADR in the settlement of land conflict in the rural area of Bangladesh.

\section{Various Forms ADR Practices in Bangladesh to Resolve Land Dispute}

ADR is a process of settlement of dispute beyond the existing court procedure through mutual concession and agreement either by the parties themselves or through their representatives or through neutral third party. ADR is a means of settlement of conflict without following the prescribed court procedure, which may brings bad exposure, acerbity, high expense and high technicality (Sayed, 2006). It means resolving dispute between the parties through such means which are substitute to official litigation. The term "ADR" does not always mean alternative to formal litigation and very often it is a part of litigation particularly those ADR processes which are court annexed or judicial and it is binding upon the parties even if they do not agree with the result, as like as a judicial decision. It is an outmoded acronym that survives as a matter of convenience only (Stipanowich, 2004). ADR means "Appropriate Dispute Resolution" rather than "Alternative Dispute Resolution" (Sternlight, 2007). Figure 1 shows that prevailing ADR system in Bangladesh may be informal, formal or court annexed and quasi-formal. 


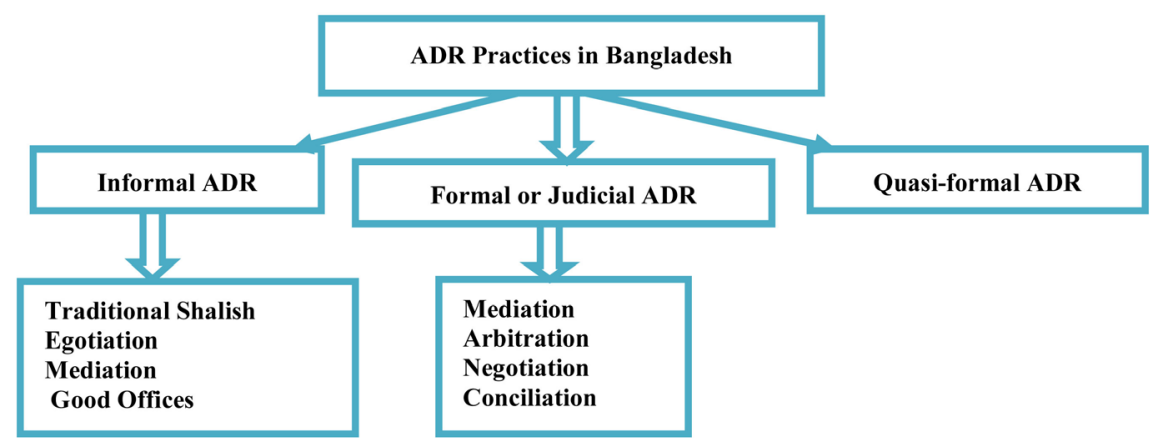

Figure 1. Shows that prevailing ADR system in Bangladesh may be informal, formal or court annexed and quasi-formal.

Court annexed or formal or judicial ADR refers those alternative methods of settlement of dispute which have set forth in the various statutes and conduct by the court itself or by the mediator appointed from the panel list or by the person outside of the panel list upon the reference of the court. It tends to be more formal in the sense that its records and proceedings may be required to be presented before the court. Informal ADR means those ADR which conduct by non-judicial body at the community level. It tends to be informal in the sense that the parties and the mediator do not need to keep any record of their proceeding. It is very much flexible, which does not follow the rules of Code of Civil Procedure, 1908 regarding pleadings or written statement or to follow the rules of the Evidence Act, 1872. Quasi-formal ADR refers to those methods of settlement of dispute which are governed by statute but does not conduct by any judicial body.

\subsection{Mediation}

Mediation is a process through which efforts are made for the settlement of dispute. It is a voluntary, confidential and informal process where conflicting parties have freedom to select impartial third party who not only offers his services but also actively participates in the talk to resolve the dispute (Kapoor, 2014). "It denotes a process in which a neutral third party helps disputants to resolve a dispute through mutual consent but does not impose any binding decision" (Ha$\mathrm{lim}, 2011)$. It is a method of resolution of dispute where a neutral person supervises the negotiation between the conflicting parties but does not impose any binding decision. In mediation, experienced individuals designated as mediator try his level best by bringing conflicting parties together, to resolve through mutual agreement between the parties (Rahman, 2015). Unlike a judicial settlement or arbitration, in mediation the third party who superintends the negotiation has no authority to give any decision binding upon the conflicting parties except assisting to reach a solution (Bhat, 2013). "In mediation the parties have the opportunity to describe the issues, discuss their interests, understanding and feelings provided each other with information and explore ideas for the resolution of the dispute" (Akhtaruzzaman, 2011). Avoidance of court complexity, easier, 
informal and speedy proceeding, cost effective, opportunity to select external expert neutral third party etc. are the main advantages of mediation.

\subsection{Arbitration}

By the term arbitration means the method through which a dispute is referred to specific persons called arbitrator and their decision is known award. The arbitrators give award only on the basis of the merits after an expedited, adversarial hearing where each of the conflicting parties has an opportunity to present proofs and arguments in support of his claim. It does not follow more formalities like judicial settlement and the parties are at liberty to set substantive law and procedural rules. In comparison with traditional trial process, it can complete more speedily and easily (Mian \& Hosain, 2013). The arbitration may be two types i.e. binding and non-binding. Award of binding arbitration is final and like the decision of a court can be enforced by the court and the award of non-binding arbitration is suggested which can be final if accepted by all the parties. "Arbitration is a process of adjudication of a dispute or controversy on fact or law or both outside the ordinary civil courts by one or more persons to whom the parties who are at issue refer the matter for decision" (Akhtaruzzaman, 2011).

\subsection{Conciliation}

Conciliation is such a method where neutral third party tries to resolve the dispute. After the matter is referred to the conciliator they meet separately with parties of the conflict and submit report and recommend certain measures for the settlement of the dispute but it is not obligatory to the parties' concern. Conciliator has no authority to take evidence or call witnesses and cannot give any decision or award only can recommend some measures by the fulfillment of which dispute can be resolved (Dhar, 2004). The conciliator may indicate the strong and weak point of disputed matter and the consequences of failure to settle (Khan, 2007).

\subsection{Negotiation}

Negotiation is a method of settlement of dispute where parties of the dispute face to face discuss their problem without interval or assistance of third party with a view to reach an amicable settlement. It is that way through which parties of the dispute voluntarily seek a mutually acceptable decision to settle their dispute (Halim, 2011). It is very informal than any other form of ADR. There is direct bargaining between the conflicting parties and no arbitrator or mediator is required to take part in the negotiation process. The most advantage of this process is the parties themselves can exercise bargaining power. When negotiation process is continued the parties must refrain from doing such acts which may have adverse effects on the process of negotiation (Alam, 2000).

\subsection{Traditional Shalish (Arbitration)}

From ancient time in Indian subcontinent, petty dispute in the rural areas was 
settled by tradition shalish (Akhtaruzzaman, 2011). Shalish a non-state justice delivery system and a reformed version of shalish is being administered as village court under statutory arrangements. ADR is of very recent origin whereas shalish as a mechanism of informal justice delivery which exists in the society of this subcontinent including Bangladesh for time immemorial (Halim, 2011). "It is a conventional method of maintaining peace and justice in the rural areas of Bangladesh which is actually a practice of assemblage village elders and concerned parties, exclusively male, for the resolution of local dispute. It has no fixed dimension and its size and structure depend completely on the nature and gravity of the problem at hand" (Khair, 2004). People of the rural areas of Bangladesh have tremendous trust in shalish as a first stratum towards seeking justice and resolution of conflict.

\subsection{Good Offices}

Although good offices as a method of settlement of international disputes is very popular but it is also prevail in the rural areas of Bangladesh as a peaceful means of settlement of dispute. As in rural areas of Bangladesh most of the land conflicts are among close relatives or neighbors, the common relatives or common neighbors of both of the parties of the dispute sometimes may create such an environment as may be helpful for the settlement of the dispute and the parties may themselves mutually negotiate the matter. Though they provide services and may put some general suggestions for the settlement but do not actively take part in the negotiation (Kapoor, 2014).

\section{Benefits of ADR in the Settlement of Land Conflict in Bangladesh}

The necessity of ADR is unlimited in the settlement of civil conflict in the rural areas of Bangladesh. Not only civil conflict but also in the settlement of commercial dispute and family dispute ADR is an important method of settlement. It always focus in the future and not past, it emphases on reestablishment of the relationship rather than exposure of the cause, it maintains good relationship and cooperation rather than determine the liability (Akhtaruzzaman, 2011). The most benefit of ADR mechanism is it could create legal awareness among mass people and able to reduce hostility (Singh, 2016). It is very simple and flexible process which avoids complexity of formal court system. It opens new avenue to apply the principle of equity rather than the strict principle of rule of law. It creates opportunity of direct dialogue between the conflicting parties with potentially higher levels of confidentiality as public records are not typically kept. It always tries to maintain win-win situation and also ensures access to justice especially for the backward groups of the rural areas who do not have adequate means to go to the court. Moreover, it protects the conflicting parties from the curse of delay and saves money and energy and also reduces work volume of the court officials. 


\section{ADR in the Legal Framework of Bangladesh for the Settlement of Land Dispute}

Formal ADR processes for the settlement of land dispute in the rural areas of Bangladesh are regulated by the following statutes.

\subsection{The Code of Civil Procedure, 1908 (Amendment, 2012)}

The process of mediation and arbitration as dispute settlement method has been included in section 89A and 89B of the code of civil procedure, 1908. Section $89 \mathrm{~A}$ states, in case of any civil suit excluding those suits which have been filed under the Artha Rin Adalat Ain, 2003, after filing of the written statement by the opposite party, the court adjourning the hearing of the suit itself mediate the dispute or refer the dispute to the concern legal aid officer or to the pleaders of the parties or to the parties of the dispute or to any mediator of the which prepared by the District Judge consulting with the President of the concern District Bar Association, to resolve the matter through mediation. The condition for being a mediator is that he may be an advocate or retired judge or persons having expertise in the dispute settlement mechanism or any other person as the parties concern think appropriate for the settlement of the dispute but if any person holds any profitable office in the service of the republic will be treated as disqualification to be a mediator of the panel. If any pleader has engaged in the suit by either party, is also disqualified to be a mediator of the panel. Concern parties, their pleader and mediator are at liberty if the parties mutually agreed, to determine the process to be followed for disposal by mediation and also to determine the fee of the mediator and in this regard court will not give any direction and if the court itself mediate determine the process to be followed by itself and shall not be entitled for any fee.

A mandatory time limit has been inserted to complete the mediation process. When the court refers the matter to the mediator to mediate, the parties have to inform to the court in writing within ten days whether they are agreed to resolve the matter or not and the time limit to complete the total mediation process is sixty (60) days from the date the court so informed and further thirty (30) days may be extended if all the parties jointly applied to the court. The mediator strictly maintaining confidentiality submit a report to the court concerning the result of mediation where the mediation process is success the terms and conditions of compromise shall be written in the form of an agreement where the parties will be the executants and the mediator and pleaders will be witnesses and the court shall pass an order or a decree under order XXIII of the code of civil procedure on the basis of the agreement of the parties. If the court itself mediate also make a report and pass an order following the similar procedure and there will have no provision of appeal or revision if the court passes a decree or order on the basis of resolution through mediation. The court shall also issue a certificate in fovour of the parties to refund the court fees paid by them. If the mediation process fails the suit shall start from the stage at which it stood before the 
decision to mediate. If the court itself mediates, and the mediation process fails than the same court shall not hear the suit.

Section $89 \mathrm{~B}$ states at any stage of the contesting parties may apply to the court to withdraw their suit on the ground that they agree to resolve their dispute through arbitration then the court granting their application permit the suit to be withdrawn and then the dispute shall be resolved according to the provisions of Shalish Ain, 2001 (Arbitration Act, 2001). If the arbitration proceedings fail, the parties are allowed to reinstitute the suit.

The parties are also allowed to mediate their dispute in appeal stage and regarding mediation in appeal stage the same procedure shall be followed as stated in section 89A of the Code of Civil Procedure, 1908 (Amendment, 2012). Parties of any suit or appeal, pending in any court before the introduction of the code of civil procedure, 1908 (Amendment, 2012) may resolve their dispute through mediation process as stated in section $89 \mathrm{~A}$ in case of pending suit and in section $89 \mathrm{C}$ in case of pending appeal. If any mediation process is for resolution any dispute is pending under section $89 \mathrm{~A}$ or $89 \mathrm{C}$ before the introduction of the Code of Civil Procedure, 1908 (Amendment, 2012) such mediation shall continue in the manner as if the provision of section $89 \mathrm{~A}$ or $89 \mathrm{C}$ were not amended by the Code of Civil Procedure, 1908 (Amendment, 2012).

\subsection{The Village Court Act, 2006}

The term "village court" has been mentioned in the Village Court Act, 2006. According to section 19 of the Penal Code, 1860 the process of the village court is not conducted by any judge. Any party of a dispute may apply to the Chairman of the Union Parishad who shall constitute a village court and the member of the village court will be five. The Chairman of the Union Parishad will be the chair of the village court and each party will select two members of them one must the member of Union Parishad. The decision of the court is given on the basis of majority. The court has jurisdiction to try all petty civil and criminal matters specified in the schedule. The court has no jurisdiction to impose imprisonment. In case of land conflict, it has jurisdiction only where value of the subject-matter does not exceed TK 75,000/=(Seventy five thousand) and it has jurisdiction to pass an order of compensation for damages to property by cattle and restitution of immoveable property. The provisions of the Evidence Act, 1872, the Code of Civil Procedure, 1908 and the Code of Criminal Procedure, 1898 are not applicable to the village court. Parties could not engage pleader to conduct their case to the village court.

\subsection{The Conciliation of Disputes (Municipal Areas) Board Act, 2004}

The conciliation of disputes board shall consist of five members. Chairman of the Paurashava shall be the chair of the board and the plaintiff have to select two members one of them must be a commissioner of the Paurashava and the defendant have to select two members one of them must be a commissioner of the 
Paurashava. The board shall have jurisdiction to try petty civil and criminal cases as mentioned in the schedule. In land dispute, the board can pass an order for damages or compensation wrong to immoveable property and restitution of immoveable property but cannot impose any fine or imprisonment. The board shall give decision on the basis of the majority. If the decision is given unanimously or one fourth majority (4:1) or one third majority (3:1) in case where one of the members was absent, the decision is final and no appeal shall be allowed and if the decision is given on two third (3:2) majority the aggrieved party can file an appeal to the concerned joint district judge within thirty (30) days from the date of decision.

\section{Administrative Challenges of ADR in the Way to Resolve Land Conflict in the Rural Areas of Bangladesh}

ADR system has included in the civil justice system of Bangladesh more than a decade ago to resolve civil conflict including land dispute outside of the court as a flexible, speedy, cost effective and peaceful means. Although more than a decade has elapsed ADR mechanism has not become truly functional to resolve land dispute of the country. The expected success of ADR mechanism in land conflict of Bangladesh that is to reduce backlog of cases and to provide swift and cost effective remedy without following complex procedure of the court has met with failure (Ahmed, 2014). Some legal and administrative challenges are facing by the ADR in the way of settlement of land dispute mainly in the rural areas of Bangladesh are enunciated below:

\subsection{Rule of Law}

Ensure the rule of law is the first challenge of ADR in the land dispute litigation in Bangladesh. ADR mechanisms are instruments of equity rather than instruments of law. In most of the cases rule of law is absent. As it emphasis on the settlement of dispute, may resolve similar dispute in different ways and due process of law is not followed in ADR.

\subsection{Imbalance of Power between the Parties}

The imbalances of power between the conflicting parties are the result of discriminatory norms in society, where there is imbalance of power between the parties; it is one of the major challenges of ADR to work well. Even if the imbalance is not a reflection of discriminatory social norms, ADR system cannot ensure legal and procedural protection to the weaker parties. Parties having money and muscle power may press the weaker to accept an unfair result. So, though it appears the settlement is consensual but it is under coercion.

\subsection{Preclusion of Systemic Injustice or Discrimination}

ADR mechanism oft reflects the common norms of society. These norms sometimes may cause injustice or discrimination to specific section or group of the 
society. ADR system cannot prevent these systemic injustices or discrimination rather hinder standards of group or individuals rights.

\subsection{To Include All Interested Stakeholders}

In case of multi-party dispute, it is a challenge to include all interested stakeholders in ADR mechanism. Inland dispute possession is important fact and usually the party who is in possession whether right or wrong is not interested in ADR because he is enjoying the output of the property. So it is very difficult to include in ADR the party who is in better possession.

\subsection{Create Public Awareness}

Most of the land litigants especially in rural areas are illiterate and unconscious who do not understand the nature and benefit of ADR. For the success of ADR it is necessary to create public awareness in the rural areas of Bangladesh.

\subsection{Role of Legal Professionals}

One of the major causes of delaying of suit is the dilatory tactics played by the lawyers. To resolve land dispute through formal or informal ADR the role of the pleaders of the concern parties is important but currently in Bangladesh the role of legal professionals to resolve a dispute outside of the court is not adequate. Generally do not cooperate in the ADR mechanism as they feel ADR will eat into their share of the pie. The lawyer community thinks that if the dispute is resolved their earning will be stopped and they always against ADR mechanism.

\subsection{Experienced and Dutiful Mediator}

Land right completely depends upon the document. For the ADR of land dispute the mediator must have proper knowledge and expertise regarding land related documents. In rural areas there is a shortage of expert and experienced mediators. As there is no arrangement of training for mediators to develop their knowledge and skill lack of experienced mediator is one of the major challenges of ADR in the way of settlement of law conflict.

\subsection{Increasing Credibility}

Traditional shalish as an informal method of ADR is playing a vital role to resolve all types of conflict including land dispute in the rural areas of Bangladesh from time immemorial. It is much effective and has adjuvant utilities as a method to resolve land dispute especially in the rural areas of Bangladesh. Shalish in rural areas of Bangladesh is influenced by money and muscle and especially by local political leaders and powerful personnel of villages and sometimes arbitrarily impose solution upon reluctant disputants (Khair, 2004). As a result shalish as an effective alternative means of dispute settlement is constantly losing credibility among the people of the rural areas of Bangladesh. Increasing credibility among the parties of the dispute in the rural areas of Bangladesh is one of 
the major challenges of ADR.

\section{Legal Challenges of ADR in the Way to Resolve Land Conflict in the Rural Areas of Bangladesh}

\section{Legal Challenges under the Code of Civil Procedure, 1908:}

i) Compel the disputants parties to attend before the court: The Code of Civil Procedure, 1908 state that mediation is compulsory and the court shall itself mediate or refer the dispute to the Legal Aid Officer or to the pleader of the parties or to the mediators from the panel to mediate when all the contesting parties attend before the court but there is no provision to compel the parties by the if any of the party does not attend before the court.

ii) No specific procedure to follow: If the court itself mediates, court shall determine the procedure to follow and if the mediation process is conducted by the legal aid officer or pleader or mediators from the panel they are at liberty to determine the procedure. But there is no explicit guideline or provision or procedure to complete the mediation process.

iii) No provision of post-trial mediation: Section $89 \mathrm{~A}$ and $89 \mathrm{C}$ of $\mathrm{CPC}$ allowed mediation at the pre-trial stage and appeal stage but provision of mediation is not incorporates after completion of the trial before the pronouncement of judgment (Islam, 2015). In reality, parties could understand the merits of their suit after conclusion of the trial.

iv) Lack of accountability of the disputants parties: Section 89A (7) state if the mediation process is not successful, the suit shall start from the stage it stood before referring to mediation. In practical, the party who is in default does not agree to negotiation and withdraws from mediation without any reasonable cause and the mediator has no other options report to the court. This process causes unnecessary delay of the suit but there is no provision to impose any fine or penalty to the party who intentionally withdraws from mediation.

v) Lack of accountability of lawyer: Most of the cases lawyers are against ADR because if the dispute is settled their income level will be reduced. In many cases, lawyers misguide or discourage their clients regarding ADR but there is no provision to ensure accountability of the lawyer in case of failure of ADR unwillingness of the lawyers.

\section{Legal Challenges under the Village Court Act, 2006}

The main challenge of village court in the way of ADR is the limitation of jurisdiction. In can resolve a land dispute where value of the property does not exceed TK. 75,000/-(Seventy five thousand). It has no jurisdiction in cases of all disputes regarding land. It has jurisdiction only in case of restitution of immoveable property and compensation for damages to the property but in case of other conflicts it has no jurisdiction.

\section{Recommendation}

Although popularity of ADR as a peaceful means of settlement of civil conflict in 
Bangladesh especially in family matters is increasing day by day but in case of settlement of land conflict its success rate is very low. Some legal and administrative challenges are constantly creating interruption in the way of success of ADR in the settlement of land conflict. These trammels can be diverged by the effectuation of the recommendation state below which will also ensure justice through fruitful ADR mechanism:

Recommendations to overcome legal challenges:

1) There should be specific procedure to be followed in case of formal mediation either by the court itself or by any other mediators.

2) The provision of post-trial mediation should be inserted in the code of civil procedure.

3) In case of court annexed ADR if the mediation fails, there should be the provision of penalty against the party for whose default mediation fails.

4) There should be the provision of penalty against the concerned lawyer if the mediation initiative fails due to the negligence of the concerned pleader.

5) The pecuniary jurisdiction of the village court should be increased and the jurisdiction of the village court should be extended in all sorts of land conflict.

Recommendations to overcome administrative challenges:

6) To get full benefit of ADR as a peaceful means of settlement of land conflict massive awareness should be created among the people of the rural areas of Bangladesh. In this regard, government can arrange various programs in each union parishad of Bangladesh. Besides these, print and electronic media as well as NGOs can play a vital role to promote awareness.

7) In case of informal ADR in rural areas, every member of the union parishad and elite people of the village who conduct mediation, have to be trained up properly regarding various techniques and rules of mediation. It will remove shortage of experienced and dutiful mediators in the rural areas of Bangladesh.

8) To remove discrimination and to ensure equal opportunity for all parties and to maintain balance of power between the conflicting parties, informal ADR especially traditional shalish must be free from political influence, money and muscle otherwise weaker party will not be interested in ADR.

9) To increase credibility traditional shalish no decision can be imposed arbitrarily upon the reluctant disputants.

10) For informal ADR there must have some specific guideline to ensure rule of law and also to prevent systemic injustice.

11) Person involved in legal profession must be cordial otherwise the success of ADR will remain such a dream that never becomes true.

\section{Conclusion}

The land litigation system in Bangladesh is so costly, so painful, so destructive, so complex and so much insufficient that sometimes justice seeker becomes victim of injustice. To get relief from suffering, people especially rural areas of Bangladesh always preferred alternative dispute resolution outside of the formal 
court system. As a speedy, cost effective, flexible and confidential means of settlement of land dispute ADR has got popularity among the people of the rural areas of Bangladesh. It is a means of settlement where no one is defeated as it always maintains win-win situation. Court annexed or formal ADR was included in land litigation of Bangladesh in 2003 by inserting section 89A, 89B and 89C in the code of civil procedure as a voluntary means of settlement civil suit and it is made compulsory in 2012. Informal ADR is practicing in this sub-continent from time immemorial and has been playing a vital role to ensure justice among the marginalized people of the country. As an alternative means of settlement of dispute in the rural areas traditional shalish has potential utilities and court annexed ADR is a symbol of integrity, neutrality and authenticity. Although ADR system has brought a revolutionary change in the settlement of civil conflict in the alternative way other than court, it is now facing various legal and administrative challenges which are continuously creating obstruction in the way of delivery of justice. To ensure easy, speedy and low cost justice for all especially for the poor people of the rural areas who cannot maintain formal court procedure due to financial and other constraints in land litigation, these legal and administrative challenges must be removed by proper initiatives.

\section{Conflicts of Interest}

The authors declare no conflicts of interest regarding the publication of this paper.

\section{References}

Ahmed, Z. (2014). Laws on Alternative Dispute Resolution: Theory and Analysis. Dhaka: Muhit Publications.

Akhtaruzzaman, M. (2011). Concept and Laws on Alternative Dispute Resolution and Legal Aid (4th ed.). Dhaka: Razia Khatun.

Akram, M. S. (2017). A Critical Analysis of Access to Justice in Bangladesh. International Journal of Humanities and Social Science Invention, 6, 50-58.

Alam, M. S. (2000). Contemporary International Law. Dhaka: New Warsy Book Corporation.

Bhat, I. H. (2013). Access to Justice: A Critical Analysis of Alternative Dispute Resolution Mechanisms in India. International Journal of Humanities and Social Science Invention, 2, 46-53.

Chowdhury, S. (2017). Lower Grade Staffs of the Land Office have Problems. The Daily Proyhom Alo.

Dhar, N. (2004). Labour and Industrial Laws of Bangladesh. Dhaka: ReMisi Publisher.

Halim, M. A. (2011). ADR in Bangladesh: Issues and Challenges (2nd ed.). Dhaka: CCB Foundation.

Hoque, K. N. (2000). Land Law and Development of Land System (p. 255). Dhaka.

Islam, K. M. (2015). Critical Review of the Court Based ADR in Bangladesh: Prospects and Challenges. IOSR Journal of Humanities and Social Science (IOSR-JHSS), 20, 45-55. 
Islam, M. S. (2011). Efficiency and Effectiveness of Alternative Dispute Resolution Schemes towards the Promotion of Access to Justice in Bangladesh. International Islamic University Chittagong Studies, 8, 95-112. https://doi.org/10.3329/iiucs.v8i0.20405

Kapoor. S. K. (2014). International Law and Human Rights (19th ed.). Allahabad: Central Law Agency.

Khair, S. (2004). Alternative Dispute Resolution: How It Work in Bangladesh. The Dhaka University Studies, 15, 59-92. https://doi.org/10.1007/978-1-4612-2040-4_7

Khan, A. A. (2007). An Introduction to Alternative Dispute Resolution (ADR). Dhaka: Hira Publication.

Mian, M. N., \& Hossain, S. R. (2013). Problems of Alternative Dispute Resolution Mechanisms and Proposals for Improvement: A Study in Bangladesh. International Journal in Management and Social Science, 1, 22-32.

Naser, M. M. (2006). The Role of Clinical Legal Education in Increasing Access to Justice: The Context of Bangladesh. In Commonwealth Legal Education Conference.

Rahman, M. M. (2015). Access to Justice and ADR in Bangladesh: Institutional and Legal Frameworks. ASA University Review, 9, 241-254.

Sayed, K. R. (2006). Alternative Dispute Resolution in Malaysia. Kualalampur: Kuliyyah of Laws, IIUM.

Singh, A. K. (2016). ADR Mechanism in India: Achievements and Challenges. Indian Journal of Research, 5, 112-115.

Sternlight, J. R. (2007). Is Alternative Dispute Resolution Consistent with the Rule of Law? Lessons from Abroad. De Paul Law Review, 56, 569-592.

Stipanowich, T. J. (2004). ADR and the "Vanishing Trial": The Growth and Impact of “Alternative Dispute Resolution”. Journal of Empirical Legal Studies, 1, 843-912.

https://doi.org/10.1111/j.1740-1461.2004.00025.x 